\title{
Manavgat İlçesinin Örtüaltı Sebze Yetiştiriciliğinde Kirletici Faktörler ve Çevresel Etkilerinin Belirlenmesi
}

\author{
Atılgan Atılgan ${ }^{1}$, Ümran Sarı $^{2}$, Burak Saltuk ${ }^{3}$, Hasan Ertop ${ }^{4}$ \\ ${ }^{1}$ Alanya Alaaddin Keykubat Üniversitesi Rafet Kayış Mühendislik Fakültesi Biyosistem Mühendisliği Bölümü Alanya-Antalya/Türkiye \\ (ORCID:0000-0003-2391-0317) atilgan.atilgan@alanya.edu.tr \\ Isparta Uygulamalı Bilimler Üniversitesi, Ziraat Fakültesi, Tarımsal Yapılar ve Sulama Bölümü., Isparta/Türkiye \\ (ORCID: 0000-0003-0116-8756) umran.sariii07@gmail.com \\ Alanya Alaaddin Keykubat Üniversitesi Rafet Kayış Mühendislik Fakültesi Biyosistem Mühendisliği Bölümü Alanya-Antalya/Türkiye \\ (ORCID: 0000-0001-8673-9372)burak.saltuk@alanya.edu.tr \\ Isparta Uygulamalı Bilimler Üniversitesi, Ziraat Fakültesi, Tarımsal Yapılar ve Sulama Bölümü., Isparta/Türkiye \\ (ORCID: 0000-0003-0987-5885) hasanertop@,hotmail.com
}

(Illk Geliş Tarihi 23 Haziran 2021 ve Kabul Tarihi 22 Ağustos 2021)

(DOI: 10.31590/ejosat.956632)

ATIF/REFERENCE: Manavgat İlçesinin Örtüaltı Sebze Yetiştiriciliğinde Kirletici Faktörler ve Çevresel Etkilerinin Belirlenmesi European Journal of Science and Technology, (25), 802-809.

\section{$\ddot{O} \mathbf{z}$}

Dünyayı saran pandemi nedeniyle insanların daha çok sebze ve meyve tüketme isteği ortaya çıkmıştır. Ayrıca ülkemizin 1lıman bir iklime sahip olmasının yanında toplum bilincinin gelişmesi sonucunda son yıllarda ülkemizde yıllık sebze ve meyve tüketiminin arttığı gözlenmektedir. Sera yetiştiriciliğ̣i, tarımın en önemli gelir getirici dallarından birisidir. Sıcak iklim kuşağındaki ülkelerde olduğu gibi Akdeniz Bölgesindeki seralarda ekonomik ve montaj kolaylı̆̆ bakımından yaygın olarak plastik örtü malzemesi tercih edilmektedir. $\mathrm{Bu}$ çalışmada, Manavgat Tarım ve Orman İlçe Müdürlüğünde çalışan teknik elemanların önerileriyle seracılık faaliyetlerinin yoğun yapıldığı Manavgat merkezdeki ve merkeze bağlı köylerdeki seralar incelemeye alınmıştır. Seralara ait arazi büyüklüklerine ilişkin istatistiksel veriler, basit tesadüfi örnekleme yöntemiyle, anket yapılarak belirlenmiştir. Alınan bilgiler doğrultusunda Manavgat yöresindeki 124 adet işletme materyal olarak tespit edilerek, araştırma alanı içinde işletmelere ayrı ayrı olarak gidilmiştir. Yapılan çalışmayla Manavgat yöresinde örtüaltı sebze yetiştiriciliğinin tüm aşamalarında yapılan tüm tarımsal faaliyetler tespit edilmiştir. Aynı zamanda tüm bu faaliyet aşamalarında çevre kirliliği ve çevresel sorunlara neden olan her türlü parametreler belirlenmiştir. Yapılan bu araştırma ile tarımsal anlamda oluşabilecek kirliliğin engellenerek, sürdürülebilir bir çevrenin sağlanması amacıyla ilkelerin belirlenmesi ve yapılan çözüm önerileri ile üreticilere fayda sağlayarak doğanın da korunması beklenmektedir. Bu kapsamda dönem dönem üreticiler ile bir araya gelerek gerekli eğitimlerin verilmesi gerektiği kanısına varılmıştır. Dolayısıyla bu eğitimlerin biyolojik mücadele, yeşil gübre uygulamaları ile birlikte yapılacak iyi tarım uygulamalarını kapsayan bilinçlendirme çalışmaları için atılacak adımların örnek olacağı kanısına varılmıştır

Anahtar Kelimeler: Sera, Manavgat, Çevre kirliliği, Sebze yetiştiriciliği

\section{Determination of Pollutant Factors and Environmental Effects in Greenhouse Vegetable Cultivation of Manavgat District}

\begin{abstract}
:
Due to the pandemic surrounding the world, people's desire to consume more vegetables and fruits has emerged. In addition to the warm climate of our country, it is observed that the annual consumption of vegetables and fruits in our country has increased in recent years as a result of the development of public awareness. Greenhouse cultivation is one of the most important income generating branches of agriculture. Plastic cover material is widely preferred in greenhouses in the Mediterranean Region, as in countries in the warm climate zone, in terms of economy and ease of installation. In this study, greenhouses in Manavgat district and its affiliated centers, where greenhouse activities are intense, were examined with the suggestions of the technical staff working in the Manavgat Provincial Directorate of Agriculture and Forestry. Statistical data on land sizes of greenhouses were determined by simple random sampling method, by conducting a survey. In line with the information received, 124 enterprises in the Manavgat region were identified as material, and the enterprises within the research area were visited separately. With the study, all agricultural activities carried out at all stages of greenhouse vegetable cultivation in the Manavgat region were determined. At the same time, it has enabled the determination of all kinds of parameters that cause pollution and environmental problems in all these activities. With this research, it is expected to protect the nature by preventing the pollution that may occur in the agricultural sense, by determining the principles in order to provide a sustainable environment and by providing benefits to the producers with the solution suggestions. In this context, it was concluded that the necessary training should be given by meeting with the producers from time to time. Therefore, it has been concluded that these
\end{abstract}

Corresponding author ${ }^{3}$ Alanya Alaaddin Keykubat Üniversitesi Rafet Kayış Mühendislik Fakültesi Biyosistem Mühendisliği Bölümü AlanyaAntalya/Türkiye (ORCID: 0000-0001-8673-9372) burak.saltuk@alanya.edu.tr 
trainings will be an example of steps to be taken for awareness-raising activities covering biological control, green manure applications and good agricultural practices.

Keywords: Greenhouse, Manavgat, Environment pollution, Vegetable cultivation,

\section{Giriş}

Günümüzde insanların gıda ihtiyaçlarını karșılamak için daha fazla üretime ve daha fazla verimliliğe ihtiyaç duyulmaktadır. Seralar, iç ortamda sıcaklık, ışık ve nem gibi iklimsel faktörlerin kontrolü ile üretim yapılabilen, dış ortam iklim koşullarına tamamen veya kısmen bağlı olan ve yıl boyunca sebze, tohum ve fideler üretmek için kullanılan bitkisel üretim yapılarıdır (Anonim, 2015, Baytorun, 2016; Büyüktaş ve ark., 2016).

Türkiye'nin her yerinde seracılık faaliyetinin yapılması ekonomik olmamaktadır. Gerek iklim şartlarından gerekse pazar payının düşük olmasından dolayı Akdeniz bölgesinin kıyı kesimleri seracılık için ideal görülmektedir. Ilıman iklime sahip
Akdeniz Bölgesinde diğer seralara göre plastik örtülü seralar ilk yatırım maliyetlerinin düşük olması nedeni ile daha fazla kullanım alanları oluşturmaktadır. 2020 yılı verilerine göre ülkemizdeki örtüaltı miktarının 21825.1 ha'lık kısmı alçak tünel, 10387.2 ha'lık kısmı yüksek tünel, 40104.3 ha'lık kısmı plastik sera ve 8073.6 ha'lık kısmı ise cam sera olup toplam örtü alanı 80390.2 hektardır (Anonim, 2021).

Dünya'da örtüaltı yetiştiricilik faaliyeti konusunda ülkelere göre örtüaltı alan miktarına bakıldığında ülkemiz yaklaşık 64911 ha örtü altı üretim alanı ile İtalya 72800 ha ve 71698 ha ile İspanya'dan sonra 3. sırada yer aldığ 1 bilinmektedir (Tüzel ve Öztekin, 2015).

Çizelge 1. Türkiye'nin Bölgelere Göre Örtüaltı Varlığı (Anonim, 2021).

\begin{tabular}{|l|c|c|c|c|c|}
\hline Bölge Adı & Alçak Tünel (da) & Cam Sera (da) & Plastik Sera (da) & Yüksek Tünel (da) & Toplam (da) \\
\hline Akdeniz & 212106 & 73362 & 330019 & 69646 & 685133 \\
\hline Ege & 5234 & 6806 & 51462 & 12744 & 76246 \\
\hline Marmara & 101 & 274 & 10833 & 9245 & 20453 \\
\hline Karadeniz & 709 & 4 & 4018 & 11698 & 16429 \\
\hline İç Anadolu & 30 & 79 & 618 & 273 & 1000 \\
\hline Güneydoğu Anadolu & 40 & 160 & 2039 & 25 & 2264 \\
\hline Doğu Anadolu & 31 & 51 & 2054 & 241 & 2377 \\
\hline
\end{tabular}

Çizelge 1'de 2020 yılı için bölgelerin niteliklerine göre örtüaltı yetiştiricilik varlığ 1 dekar olarak ifade edilmiştir. Buna göre, örtüaltı yetiştiricilik faaliyetini en çok yapan bölge 685133 da ile Akdeniz bölgesidir. Akdeniz bölgesini 76246 da ile Ege bölgesi, 20453 da ile Marmara, 16429 da ile Karadeniz, 2377 da ile Doğu Anadolu, 2264 da ile Güneydoğu Anadolu ve 1000 da ile İç Anadolu bölgesi takip etmektedir (Anonim, 2021a). Ülkemizde iller arasında örtüaltı yetiştiricilik faaliyeti bakımında bir kıyaslama yapıldığında Antalya ili 31222 ha ile birinci sırada gelmektedir. Antalya ilini 18841 ha ile Mersin ve 15413 ha ile Adana izlemektedir. Antalya ili içerisinde ise Manavgat 2312 ha ile Kumluca (5393 ha), Serik (4392 ha), Aksu (3533 ha), Gazipaşa (3291 ha), ve Alanya (2485 ha) ilçelerinden sonra 6. sırada yer almaktadır. Manavgat'ın toplam örtüaltı varlığ 2312 hektardır. Bu alanın \%62,17'si plastik sera, \%25,46'sı alçak tünel, \%11,23'ü yüksek tünel ve \%1,12'si cam seralardan oluşmaktadır (Anonim, 2021). Büyük yatırımcı grupların da sektöre girmesiyle hızlı gelişim gösteren modern seracılık, son on yıllık süreçte büyük bir gelişme göstermektedir. Yaklaşık her y1l 150-200 ha alan eklenmektedir. Günümüzde modern seracılık sera alanlarının \%3'ünde yapılmaktadır. Önümüzdeki on yıllık süreçte bu payın $\% 15$ seviyelerine ulaşması beklenmektedir (Eker, 2012). İç Anadolu bölgesi tarım açısından yeniliklere oldukça açık bir durumdadır. Ancak seracılığın yapılabilmesi ekonomik kazançla doğru orantılıdır. Yapılan bir çalışmada örtüaltı tarımı açısından
Kırşehir ilinin uzun yıllık iklim verileri incelenmiş, sıcaklıkların arttığı, bağıl nem oranının da azalma eğiliminde olduğu belirlenmiştir. Buna göre, ortalama uzun yıllık sicaklıkların düşük, donlu gün sayısının fazla olduğu Kırşehir ilinde isıtma maliyetleri göz önüne alındığında bu aylarda örtüaltı tarımı yapılmasının ekonomik olmadığı belirlenmiştir (Boyacı ve ark., 2016). Ülkemizdeki soğuk iklime sahip bazı bölgelerde seracılık faaliyetlerinin ekonomik olmadığı, örtüaltı yetiştiriciliğinin yoğun yapıldığ 1 bölgelerde ise mevcut seraların büyük çoğunluğunun yapısal sorunlarının olduğu yapılan çalışmalarla ortaya konulmuştur. Bu anlamda Kırşehir ilinde yapılan çalışma da sera yan duvarlarında tek kat örtü malzemesi yerine çift kat kullanılması durumunda tasarruf edilen enerji miktarının arttırılmasında oldukça önemli olduğunu belirlenmiştir (Boyacı, 2018). Akdeniz Bölgesinin ikinci büyük örtüaltı potansiyeli Mersin ilidir. Mersin ili Anamur İlçesinde yapılan bir çalışmada, muz üretimi yapılan seralarının yan duvar yükseklikleri ve çatı eğim açılarının olması gerekenden daha düşük olduğu belirlenmiştir. İncelenen seralarda mertek ve çatı yükünü taşıyan kolonların sık aralıklarla yerleştirildiği ve sera içinde tarım alanının bölündüğü saptanmıştır. Çatı ve yan duvar havalandırma açıklık oranının sera taban alanına oranı $\% 1,8$ olarak belirlenmiştir (Emekli ve Büyüktaş, 2009). Tarım ürünlerinin üretimi aşamasında kullanılan girdiler (her türlü gübreler ve ilaçlar) üretimi yapılan ürünün birim alana verimini artırıp, zararlı ve hastalıklara karşı daha dayanıklı olmasını imkân sağlarken, 
yakın çevresinde yer alan ekosistem ve canlılar üzerine olumsuz etkilerinin olduğu bilinmektedir (Parlakay, ve ark., 2015). Örtüaltı yetiştiricilik faaliyetleri süresince çeşitli kirlilik durumları oluşmaktadır. Seralarda hasat süresince ve hasat sonrasında ortaya çıkan bitkisel atıklar uygun bir şekilde yönetilmediğinde çevre ve toprak kirliliğine neden olduğu belirtilmiştir (Atılgan ve ark., 2007; Güzey ve Atılgan, 2015). Bu çalışma ile tarımsal anlamda oluşabilecek kirliliğin engellenerek, sürdürülebilir bir çevrenin sağlanması amaçlanmakta olup, çevresel ilkelerin belirlenmesi ve yapılan çözüm önerileri ile üreticilere benimsetilerek fayda sağlaması ve doğal bir sonuç olarak yöredeki doğanın korunması istenmektedir.

\section{Materyal ve Metot}

\subsection{Materyal}

Yapılan bu çalışma ile Manavgat yöresinde örtüaltı sebze yetiştiriciliği yapan işletmelerinin genel durumları tespit edilerek üretim sezonu süresince ve sonrasında ortaya çıkan tarımsal atıkların değerlendirme şartları ve bunların çevreye olası etkileri araştırılmıştır. Manavgat'ın kuzeyi Toros Dağları ile çevrilidir. Sahil şeridi plajları ve eşsiz kumsallarla kaplıdır. Denizden iç bölgelere gidildikçe ekilebilen düz ovaların yanında engebeli bir arazi yapısı gözlenir. İklimi; Akdeniz iklimi olup, yazları sıcak ve kurak, kışları 1lık ve yağışlıdır. Don olayı tüm yıl boyunca ancak birkaç gün görülmektedir. İlçenin doğal yapısı kısmen tarıma uygun olup bu bölgelerde tarım gelişmiştir. Geri kalan bölgeler olan orman ve fundalık alanlar ve hayvancılığın geliştiği köyler olarak ayrılır. İlçe köylerinde büyük ve küçükbaş hayvan yetiştiriciliğinin yanında hububat, susam, karpuz yetiştiriciliği ve özellikle son yıllarda zeytincilik giderek önem kazanmaktadır. Orman ürünleri işçiliği ve mevsimlik tarım işçiliği başlıca kazanç yolları olup sınırlı tarım arazilerinde hububat yanında son yıllarda kekik, kiraz ve ceviz gibi meyve yetiştiriciliği yapılmaya başlanmıştır. Son yıllarda pamuk üretimi azalmakta narenciye, açık alan ve örtü altı sebze yetiştiriciliğinde artma görülmektedir. İlçede sanayi gelişmemiştir. Ancak tarıma dayalı olarak pek çok fabrika bulunmaktadır. Bunlar dışında bölgenin doğal getirisi olarak turizm ilçenin en önemli gelir kaynaklarındandır. Sahil şeridinden itibaren, Toroslar'a kadar uzanan alan, tamamen ziraat alanıdır. Manavgat ilinin ekonomik olarak ana geçim kaynağı özellikle turizm ve tarımdır (Anonim, 2021b). Çalışmada materyal olarak ilçedeki seralar ve bu seralardaki atıklar ve faaliyetler materyal olarak kullanılmıştır. Manavgat'a komşu olan ilçeler ve Manavgat' 1 mahallerini gösteren harita Şekil 1.'de verilmiştir.

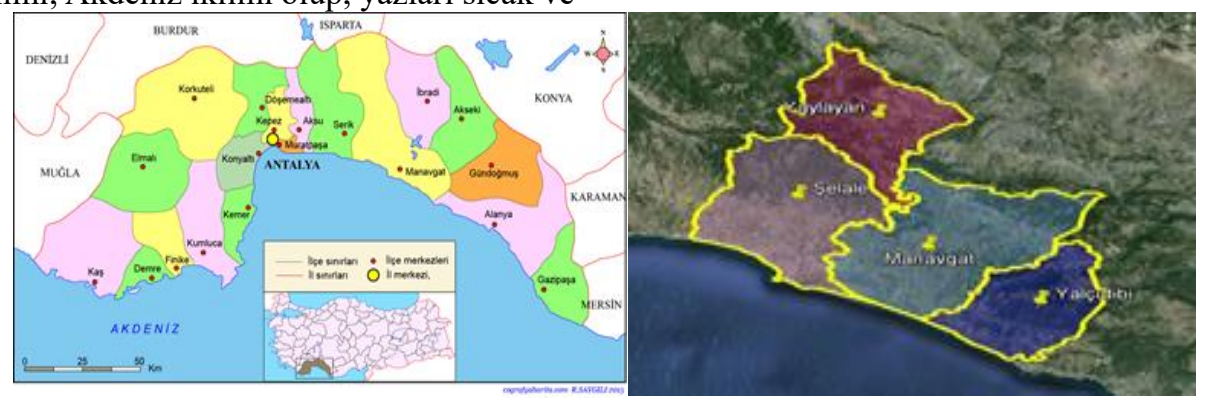

Şekil 1. Çalışmanın yapıldı̆̆ ilçe ve mahalleri gösteren harita

\subsection{Metot}

Çalışma, gerek Manavgat İlçe Tarım ve Orman Müdürlüğü çalışanlarının yönlendirmesiyle, gerekse önder çiftçilerle araziye çıkılarak yürütülmüştür. Çalışma alanı Manavgat yöresinde örtüaltı sebze yetiştiriciliğinin yoğun olarak yapıldığı belde ve köyleri kapsamaktadır. Evrenseki, Merkez, Hatıplar, Yeniköy gibi sera yetiştiriciliğini yoğun yapıldığı yerlerdeki işletme sahipleri çalışmanın hedef kitlesidir. Materyal olarak belirlenen işletmeler öncelikle Manavgat İlçe Tarım ve Orman Müdürlüğünden konuyla ilgili veriler alınarak kullanılmıştır. Elde edilen veriler aracılığıyla anket yapılan sera işletmelerinin belirlenmesi amacıyla aşağıda verilen "Basit Tesadüfi Örnekleme" yöntemi kullanılmıştır. 1'den N'e kadar numaralandırılmış olan bir popülasyondan n sayıdaki bir örnek eşit olasılıklı olarak seçilmektedir (Oğuz ve Karakayacı, 2017). n: Örnek hacmini,

N: Popülasyondaki işletme sayısını,

S: Popülasyon varyansını,

$\mathrm{d}$ : ortalamadan belirli bir orandaki (\%5) sapmayı, $\mathrm{t}$ ise $\% 95$ güven sınırına karşılık gelen $\mathrm{t}$ tablo değerini $(1,65)$ ifade etmektedir.

Anılan formül yardımı ile $\% 90$ güvenirlik sınırı ve $\% 10$ hata payı ile anket uygulanan işletme sayısı 124 adet olarak belirlenmiştir. Çalışmanın yapılabilmesi ve örtüaltı sebze yetiştiriciliği yapılan işletmelerin özellikleri hakkında daha iyi netice almak için Manavgat İlçe Tarım ve Orman Müdürlüğü’ndeki personellerin katkılarıyla yöredeki işletmeler hakkında çeşitli bilgiler alınmıştır. Alınan bilgiler doğrultusunda Manavgat yöresindeki 124 adet işletme materyal olarak tespit edilerek, araştırma alanı içindeki tüm işletmelere gidilerek anketler uygulanmıştır. (Çizelge, 2). Çıktı olarak alınan formlarda sisteme kullanıcı yardımı ile girilmiştir.

$$
n=\frac{N x S^{2} x t^{2}}{(N-1) x d^{2}+S^{2} x t^{2}}
$$

Çizelge 2. Anket Uygulanan İşletmelerin Bulunduğu Yerler 
European Journal of Science and Technology

\begin{tabular}{|c|c|c|}
\hline Yeniköy & Yukarı Işıłlar & Çardakköy \\
\hline Gündoğdu & Çavuşköy & Kızılağaç \\
\hline $\begin{array}{c}\text { Uzunkale köyü } \\
\text { güzelli mahallesi }\end{array}$ & Azizler & Kızılot \\
\hline Evrenseki & Hatıplar & Kalemler \\
\hline Örenşehir & Dolbazlar & Ilıca \\
\hline Taşağııl & Çolaklı & Sarılar \\
\hline Kalemler & Çenger & \\
\hline Manavgat merkez & Kumköy & \\
\hline Göğü & Karakaya & \\
\hline Yavrudoğan & Evrenler & \\
\hline Dikmen mahallesi & Çolaklı & \\
\hline Dolbazlar & Kayadibi & \\
\hline Sarin & Gömeçli & \\
\hline Şişeler & Hatıplar & \\
\hline Dolbazlar & Üründük köyü & \\
\hline Aşağı 1şılar & Hocalı & \\
\hline & & \\
\hline
\end{tabular}

Çalışmada materyal olarak belirlenen örtüaltı sebze yetiştiriciliği yapan işletmelerle ilgili; işletme büyüklükleri, örtü tipi, sera drenaj durumu, sera isıtma şekli, sera içi pestisit kullanımına karar verme durumu, toprak analiz yaptırma durumu, aşırı gübre ve pestisit kullanımı sonucu ortaya çıkabilecek sorunlara farkındalık durumu, üreticilerin toprak ve yaprak analizi yaptırma nedenleri, pestisit seçiminde etkili kriterler, hastalık ve zararlı teşhisi yapılma durumu, üreticilerin eğitim durumu, pestisit kullanımda tercih edilen yöntemler, üreticilerin toprak ve yaprak analizine bakış açısı, toprak ve yaprak analizi yaptırmak için istenilenler, bitkisel atıkların değerlendirilme durumu ve örtü malzemesinin geri dönüşümü gibi çeşitli özelliklere ait veriler, işletmelerde yapılan anketler, gözlemler ve çekilen fotoğraflar doğrultusunda sağlanmıştır. Materyal olarak belirlenen örtüaltı sebze yetiştiriciliği faaliyeti gerçekleştiren işletmelerden elde edilen verilere göre kirletici faktörler belirlenmiştir. Belirlenen bu faktörlerin çevre kirliliği açısından etkileri belirlenerek ortaya çıkan sonuçlar neticesinde önerilerde bulunulmuştur. Çalışmada kullanılan anketler yazılı olarak doldurulmakla beraber, aynı zamanda internet tabanlı Google formlar kısmindan elektronik ortamda da doldurulmasina olanak verilmiştir. $\mathrm{Bu}$ şekilde zaman tasarrufu sağlanmakla beraber, sonuçların daha kolay yorumlanmasını sağlamıştır. Ankete verilen cevaplar SPSS istatistik programı ile değerlendirilmiştir. Tarım İl Müdürlüğü personelleri aracılığıyla ulaşılan işletmeler olduğu gibi direk alınan anket sonuçları da bulunmaktadır. Çıktı olarak alınan formlarda sisteme kullanıcı yardımı ile girilmiştir.

\section{Araştırma Bulguları}

Manavgat ilçesinde, anket uygulanan işletmelerden elde edilen sonuçlara göre, anket uygulanan işletmelerin; alan büyüklüleri Şekil 2'de verilmiştir. Şekil 2 incelendiğinde işletmelerin $\% 51,8^{\prime}$ inin $7500 \mathrm{~m}^{2}$ den küçük alana sahip olduğu belirlenmiştir. Bununla birlikte işletmelerin \%12,1'inin 3100$4500 \mathrm{~m}^{2}$ ve \%29'unun $4600-6000 \mathrm{~m}^{2}$ alana sahip işletmeler olduğu belirlenmiştir. Seraların özellikle havalandırma açısından yeter derecede yüksekliğe sahip olması gerektiği bilinmektedir. Buna göre; çalışma alanındaki seraların $\% 52$ 'sinin sera yüksekliği 4,5 m, \%43,2'sinin sera yüksekliği 5,0 m ve $\% 4,8$ 'inin ise 4,0 m olarak belirlenmiştir. Yapısal özellikler açısından incelenen seraların birbirine benzer şekilde yapıldığı gözlenmiştir. İşletmelerin \%96'sında örtü malzemesi olarak polietilen (PE) plastik örtü malzemesi kullanılırken, \%4'ünde ise cam ve

polikarbon örtü malzemesinin kullanıldığı belirlenmiştir (Şekil 3).

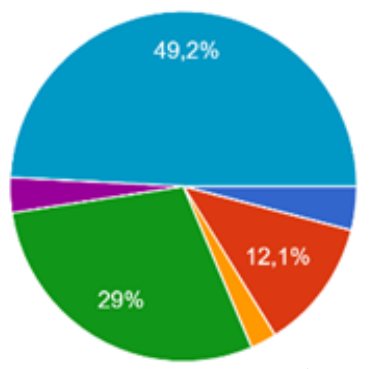

Şekil 2. İşletme Büyüklükleri

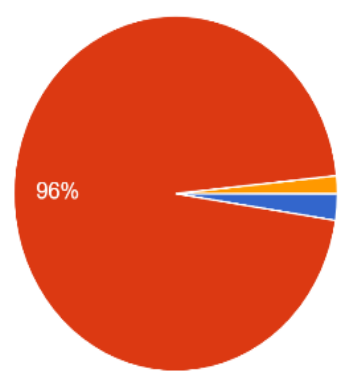

Şekil 3. Örtü Tipi

Sera örtü malzemesi seçimde PE (Polietilen) ön plana çıkmaktadır. Kullanılan malzemenin içeriğinin önem göstermediği seçimde maliyetin göz önüne alındığı bir gerçektir. Yörede örtü malzemesi kullanımında malzemenin UV (ultraviyole), IR(infrared), 1sı iletimi, 1şık geçirgenliği gibi teknik özelliklerinden ziyade maliyetinin göz önüne alındığı belirlenmiştir. Üreticiler, örtü malzemesinin dayanıklı olmasını tercih ettikleri, doğal afet olmadığı sürece 3 yıldan önce sera örtü malzemelerini değiştirmediklerini belirtmişlerdir. Yöredeki firmalar tarafından 36 ay dayanabildiği ifade edilerek satılan örtü malzemesinin kullanıldığ 1 belirlenmiştir. Üreticilerin \%68,5'i serada 1 sitma yapmadığ $1, \% 31,5$ 'inin 1 sıtma yaptı̆̆ belirlenmiştir. Fosil yakitlarla 1sitma yapanların oranı ise \%11,3'tür (Şekil 4). Ertop ve Atılgan (2017), Antalya yöresinde sera üreticileri arasında yaptıkları çalışmada en yaygın 1sıtıcı tipinin soba olduğunu ve kolay yakıt bulunabilirliğinden dolayı soba kullanımının arttı̆̆ını ifade etmişlerdir. Ertop (2017) ise, 1sıtma yapılan seralarda fosil yakıt olarak kömür kullanımın $\% 53,25$ 
olduğunu belirtmiştir. Buradan bölgedeki üreticilerin fosil yakıta olan bağlılığının devam ettiği söylenebilir. Yörenin, ısıtma giderleri iklimden dolayı fazla olmamaktadır. Ancak önceki çalışmalar 1şığında, seralarda fosil yakıtların kullanılmasının gerek çevresel gerekse maliyet açısından sorunları ortaya çıkarabilecek düzeyde olabileceği söylenebilir. Mevcut seraların \%21'inde herhangi bir drenaj sisteminin olmadığı tespit edilmiştir. Drenaj sistemine sahip seralarda farklı drenaj yöntemleri kullanılmıştır. Kullanılan bu yöntemlerin işletmeler göre dağılımı şöyledir; İşletmelerin $\% 14,5$ 'inde yeterli arazi eğimden dolayı drenajın gerekmediği, \%6,4'ünde drenajın sera etrafinda hendekler ile yüzeyde bulunan kanallarla yapıldığı ve $\% 58,1$ 'inde toprak altı drenaj sisteminin olduğu tespit edilmiştir (Şekil 5).
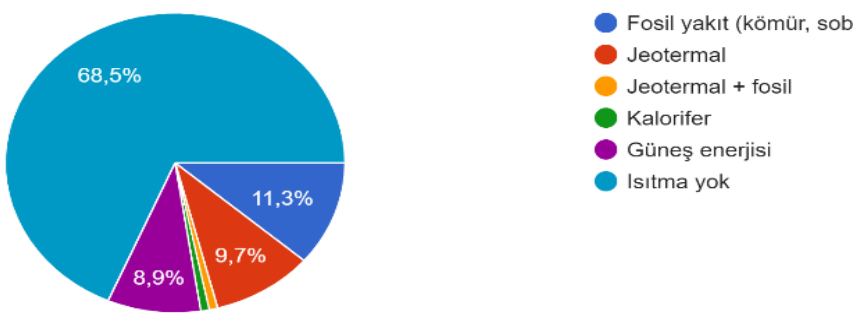

Şekil 4. Sera Isıtma Şekli

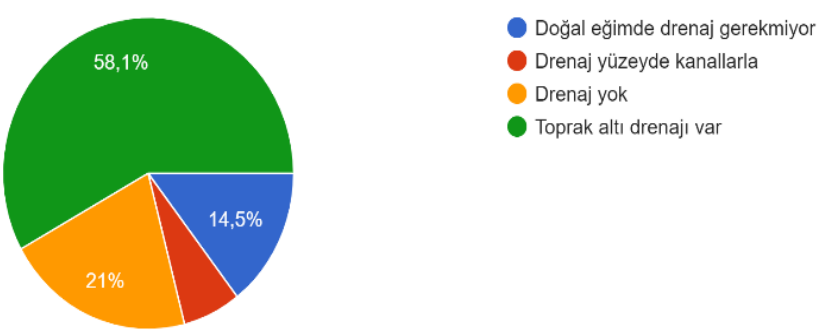

Şekil 5. Sera Drenaj Durumu

Yapılan bu çalışmadan elde edilen bulgular üreticilerin çoğunlukla sadece üretim miktarını dikkate alarak pestisit kullandıkları ve gübreleme yaptıklarını verim dışındaki kriterlere önem vermediklerini, olası çevresel problemlerini ise hiç dikkate almadıklarını açıkça ortaya koymuştur. Ayrıca, gerek tarım müdürlüklerinde görevli teknik elemanlar gerekse zirai ilaç satan bayilerle gerekli teknik bağlantının çok s1k kurulmadığı görülmüştür. Özellikle üretimin en fazla 14 hafta sürdüğü sezonluk üretimde (en fazla 3 defa) üreticilerin teknik destek alma konusunda istekli olmadıkları bunun yanı sıra yayımcılarında yeterli uygulama yapmadıkları gözlenmiştir (Şekil 6).

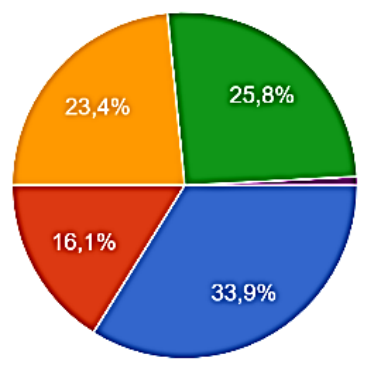

Tarla ve Bahçede ha fiilen gözlenmesi

Komşu üreticilerin ta hastalık ve zararlılar

Tarım Illfilçe Müdürlü elemanlarının öneril

İlaç bayilerinin öneril

Diğer

Şekil 6. Sera İçi Pestisit Kullanımına Karar Verme Durumu

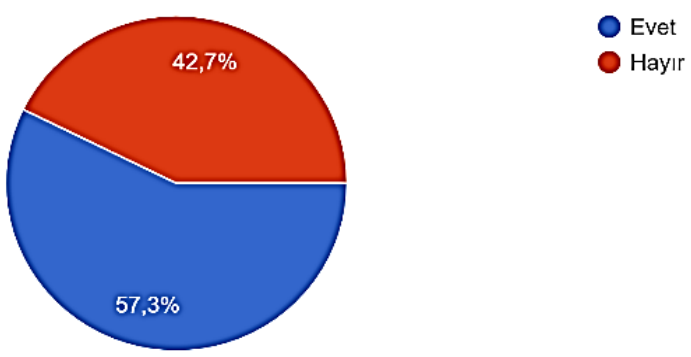

Şekil 7. Toprak Analiz Yaptırma Durumu

Toprak ve yaprak analizi yaptıran üreticilerin oranı $\% 57,3$ iken yaptırmayanların oranı ise $\% 42,7$ 'dir. Özellikle bu konuda yöredeki üreticilerin doğru bir uygulama içerisine girmeye başladıkları görülmüştür (Şekil 7). Üreticilerin toprak ve yaprak analizi yaptırma nedenleri irdelendiğinde bu analizlerdeki neden sonuç ilişkilerine yaptıkları yorum neticesinde $(\% 87,1)$ yaptıkları işin çevresel açıdan önemini fark etmeye başladıkları kanısına varılmıştır. Toprak ve yaprak analizi yaptırmadan doğru miktarda gübre ve doğru hastalık tespiti yapılmadan pestisit kullanımına yönelen üreticilerin ise bu konuda nereye başvuru yapılacağını $(\% 51,9)$ bilmediği görülmüştür. Ancak önemsemiyorum cevabı $(\% 16,7)$ verenlerde dikkat çekici düzeydedir. Özellikle bu konuda tarımsal alanda çalışan firmaların ve devlet kuruluşlarının çevresel etkileri üreticilere anlatmaları ve ikna etmeleri gereklidir. (Şekil 8 ve 9).

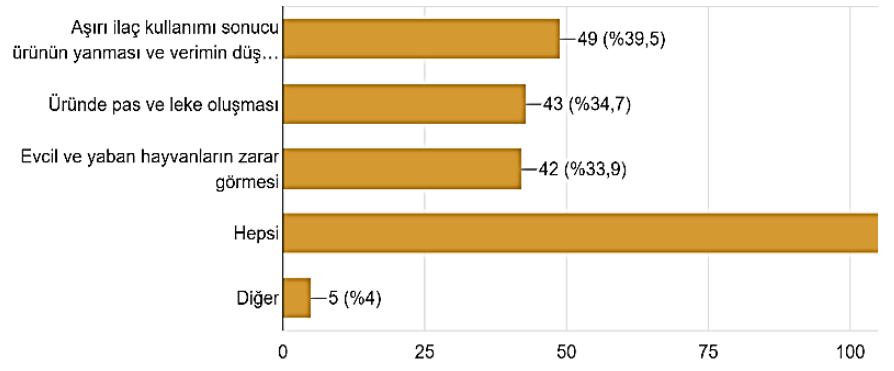

Şekil 8. Üreticilerin toprak ve yaprak analizi yaptırma nedenleri

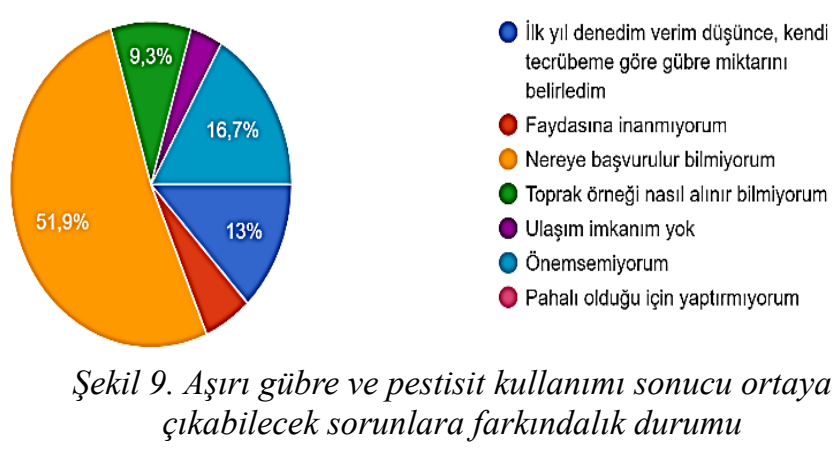

Özellikle yoğun tarım tekniklerinin uygulandığı ve kazanç odaklı üretimin ön plana çıktığı seracılıkta; pestisit kullanımının da açık tarla üretime nazaran fazla olduğu bilinen bir gerçektir. Burada temel olarak dikkat edilmesi gereken, doğru zamanda doğru miktarda ve doğru uygulamanın yapılmasıdır. Çalışmamızda pestisitte doz ayarlamasında ilaç bayilerinin tavsiyesinin göz önüne alındığı belirlenmiştir. Tanrıvermiş (2000), araştırmasında üreticilerin \% 40,2'sinin, Kalıpçı ve ark., (2011) ise üreticilerin \% 33.3'ünün ilaçlama bilgilerini ilaç 
bayilerinden aldıklarını ifade etmişlerdir. Çalışmamızın sonucunda üreticilerin geçen süre içerisinde bu alışkanlıklarının korunduğu söylenebilir. Bir bakımdan çevresel açıdan pozitif etki yarattığı düşünülse de özellikle ticari kaygıların fazla olması çevresel açıdan negatif etki de yaratabilecektir (Şekil 10, 11). Çevresel etkilere verilen önem dolaylı olarak eğitimle ilişkili bulunmuştur. Zira eğitim düzeyi arttıkça analiz yaptırmaya verilen önem artmakta, bu da gereksiz ve aşırı gübre kullanımını önlemekte ve çevresel etkiler azaltılabilmektedir.

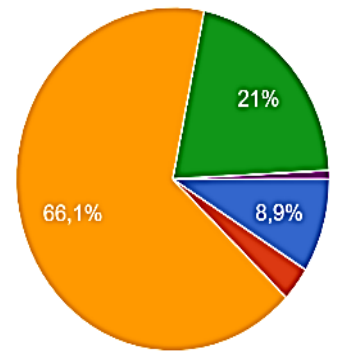

Kendi bilgi ve tecrübeme göre

Komşu ve akrabaların öneriler seçme

İlaç bayilerinin önerilerine göre

Tarım Ililiçe Müdürlüğü teknik elemanlarının önerilerine göre

Yazılı kaynaklara (Kitap, dergi, broşür vb) göre seçme

Radyo ve Televizyon Program seçme

Şekil 10. Pestisit seçiminde etkili kriterler
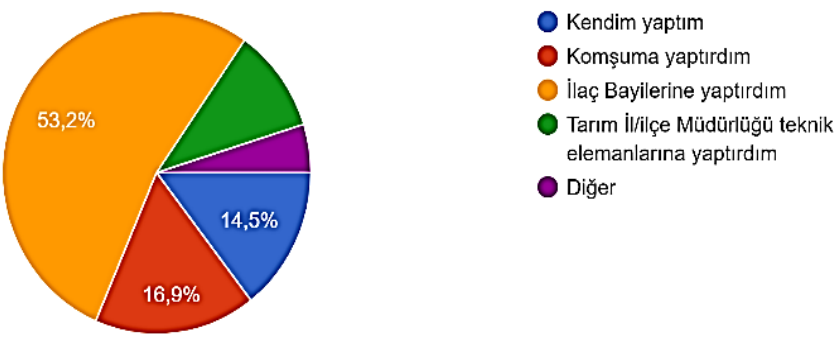

Şekil 11. Hastalık ve zararlı teşhisi yapılma durumu

Sera kaynaklı kirleticiler özellikle aşırı kimyasal gübre ve kontrolsüz pestisit kullanımı sonucu ortaya çıkmaktadır. Ancak üreticilerin büyük kısmı üretim için kimyasal gübre ve zararlılar için yoğun pestisit kullanımının sürekli olması gerektiğini savunurken toprak ve yaprak analizinin gerekli olmadığını da beyan etmektedirler. Ancak, Tiryaki ark., (2010)'nın da belirttiği gibi, aşırı pestisit kullanımı organizmalarda ilaca karşı direnç oluşturmakta, pestisit uygulaması başarısız olmaktadır. Çalışma alanındaki üreticilerin yoğun pestisit kullanımının gerekliliği düşüncesin aksine, kimyasal mücadele yöntemlerinin azaltılarak alternatif biyolojik mücadele yöntemlerine yönelim sağlanmaya çalışılması bölge tarımı için daha yararlı olabilecektir. Özellikle yoğun tarım tekniklerinin uygulana geldiği seracılıkta 5 yılda bir toprak ve yaprak analizi yapılması tamamen bilinçsize gübreleme yapıldığının veya toprak kirliliğinin önemsenmediğinin temel göstergesidir. İnsanların yanlış uygulamalarının bir sonucu olarak toprak ekosisteminin fiziksel, kimyasal ve biyolojik dengesi bozulmaktadır (Jack, 2001; Kızıloğlu Algan ve Bilen, 2005). Herhangi bir analiz sonucuna bağlı olmaksızın yapılan gübre ve pestisit uygulamaları, dekara maliyeti artırmakla birlikte bitki ve toprak açısından da olumsuz etkiler oluşturmaktadır. Ayrıca, pestisit seçiminin konusunda uzman kişiler tarafindan yapılması gereklidir. Aksi takdirde ortaya çıkacak çevresel etkiler hem insan sağlığına hem de diğer canlıların yaşam düzeylerine olumsuz etkide bulunabilir. Yapılan araştırmada üreticilerin tarım teşkilatı tarafindan yapılan uyarılara uyduklarını belirtmeleri (\%21) olumlu bir adım olarak düşünülmektedir (Şekil 12, 13).
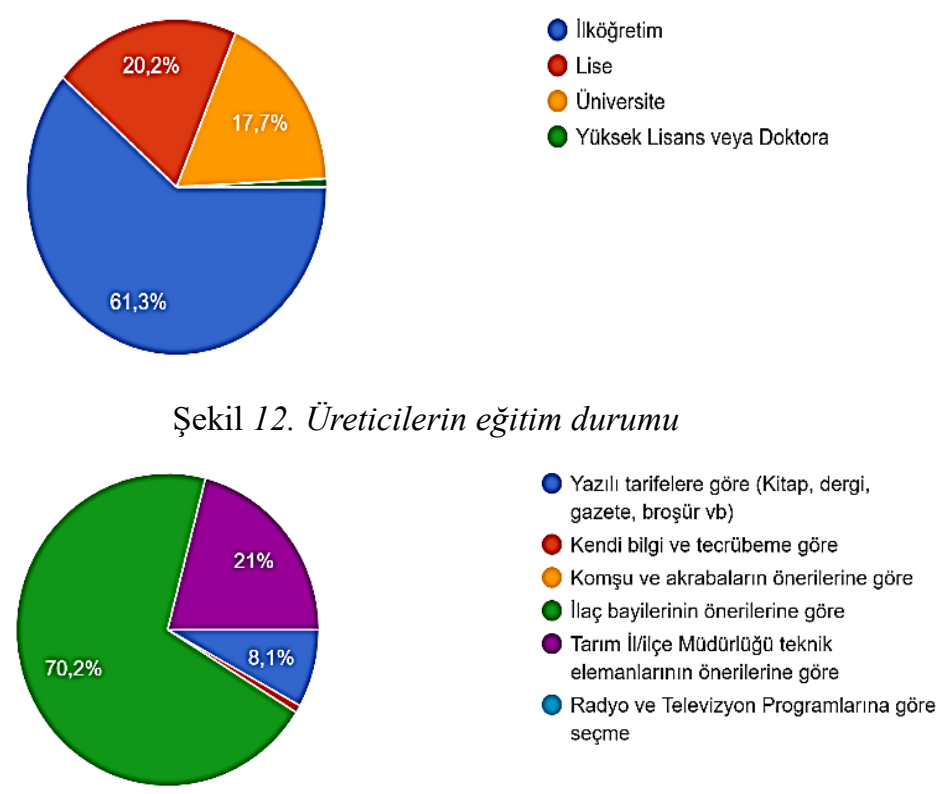

Şekil 13. Pestisit kullanımdan tercih edilen yöntemler

Yöredeki üreticilerin kısa sürede ve daha fazla ürün almayı istemesi kullandığı pestisit ve gübre miktarlarını artırmaya yöneltmektedir. Ancak sadece tüketicilerin sağlı açısından veya çevresel etkileri açısından değil aynı zamanda üreticilerin de karşılaştığı sorunlar bulunmaktadır. Çalışmanın bu bölümünde üreticilerin yüz yüze kaldığı sorunlar ve ne şekilde uygulama yapılırsa fayda sağlayabileceği konusunda verilen cevaplar irdelenmeye çalışılmıştır. Üreticilerin toprak ve yaprak analizi ile ilgili temel sorunu iki ana başlık altında yoğunlaşmaktadır. Bunlardan ilki analizin uzun zaman aldığının belirtilmesi $(\% 40,8)$, ikincisi ise analiz ile ilgili laboratuvarın bulunmaması $(\% 38,8)$ olarak belirtilmiştir. Uygulanan ankette 124 üreticinin hiç birisinin analiz sonuçlarını uyguladığımda verim düşüyor dememesi üreticilerin bilinçli olduğunu göstermektedir (Şekil 14, 15). Sadece temel sorunları tespit etmek sorunu çözmek için yeterli olmayacaktır. Bundan dolayı, çalışmamız üreticilerimizden aldığımız cevaplara göre çözüm tavsiyelerini araştırmaktır. Üreticilerimizin $\% 38,5$ 'i toprak analizlerinin zorunlu hale getirilmesini istemekte ve analiz yaptırmayanların gübre almaması gerektiğini belirtmekledir. Yüzbaşığlu (2019), tarafından Tokat ilinde yapılan bir çalışmada ise tarımsal desteklerden yararlanabilmesi toprak analizlerinin yapılması gerekliliği üreticilerin \%35,23'ü tarafından ifade edilmiştir. Çalışmamız neticesinde, farklı coğrafik bölgelerde bulunan gerek örtü altı gerek ise açık alanda üretim yapan çiftçilerin toprak analizleri kapsamındaki desteklemeler ile ilgili düşüncelerinin benzer yapıda olduğu varsayılabilir. Ayrıca, bölgesel laboratuvarların yaygınlaştırılmasının ve sürelerin kısaltılmasının istenmesi bu konuda üreticilerin istekli olduğunu da ortaya çıkarmıştır. 


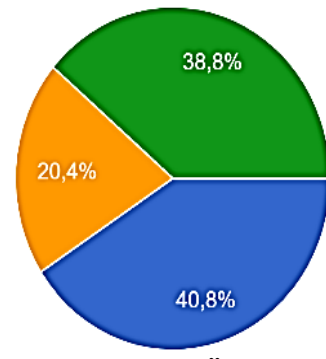

Şekil 14.Üreticilerin Toprak ve yaprak analizine bakış açısı
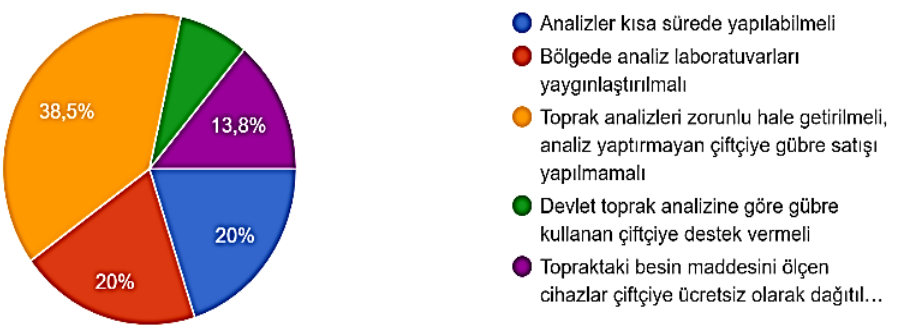

\section{Şekil 15. Toprak ve yaprak analizi yaptırmak için istenilenler}

Çevre kirliliği Dünya'nın en büyük sorunlarından birisinin olduğu bilinen bir gerçektir. Özellikle kısıtlı alanlarda yoğun uygulamalar sonucu ortaya çıkan tarımsal kirlilik günümüzün en büyük sorunlarından birisi olarak görülmektedir. Bitkisel üretiminin temel çıktısı sebze veya meyve olmakla beraber, ortaya çıkan atıkların (sap, yaprak ve kök vb) ne şeklide değerlendirdiği konusunda üreticilere yöneltilen sorularda, \%72,6's1 kompost yaptığını belirtmiştir. Üreticiler açısından oldukça iyi, çevre açısından da oldukça faydalı olacağı düşünülmektedir (Şekil 16, 17). Günümüzde, seralarda örtü malzemesi, sulama malzemesi ve malç olarak plastik (PE) kullanılmaktadır. Plastiğin (PE) uygun bir şekilde ortamdan uzaklaştırılmaması durumunda hem toprağı verimsizleştirdiği hem de geri dönüştürülemeyen atıklar arasında

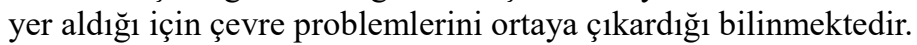
Doğada çözülmesi çok uzun yıllar alan plastik atıklar, uzun yok olma sürecinde besin zincirine girerek toprak ve su kirleticileri olarak çevreye verdiği olumsuz etkilerden dolayı ekosistemin dengesini de bozmaktadırlar (Durak, 2016). Çevreye atılan veya birakılan katı atıklardan; plastik malzemelerin 1000 yılda da ayrıştığı belirtilmektedir (Anonim, 2014; Güzey ve Atılgan, 2015). Yapılan araştırmalar, mikro plastiklerin toprakta çürümeden yıllarca kalabildiğini ve dolayısıyla mikro plastiklerin toprakta yaşayan organizmalar üzerinde olumsuz etkilerini göstermektedir (Denizli ve Yavuz, 2017). Bunun yanında; plastik poşetler toprakta ayrışmadığı için arazide kalmakta ve bitkilerin büyüme sürecini geciktirmektedir. Bitki kökleri besin maddelerine ulaşmak için toprağın içinde hareket ederken, çok ince de olsa plastik poşetleri delemedikleri için besinlere ulaşamazlar ve gelişme sürecini zamanında tamamlayamazlar (Kılıçer, 2018). Böyle bir durum ile karşılaşılması özellikle üretimin sezonluk olarak gerçekleştiği örtü altı tarımında hem ürün kalitesinin bozulması açısından hem de ürünün pazara sunulma süresi açısından istenmeyen bir durum olarak değerlendirilebilir. Organik atıkların doğadaki bozulma ve parçalanma süreleri kısa olup, inorganik maddelerin (PE örtü malzemesi) doğada çok daha özenle bertaraf gereklidir. Günümüzde tekrar değerlendirmenin maddi olarak kazanç getirmesi plastik kökenli maddelerin çevresel etkilerinin biraz da olsa azaltmıştır. Üreticilerin \%26,6'sı yakma yolu ile imha ettiğini belirtmesine karşın \%18,8'inin hurdacıya sattığını söylemesi bu
${ }^{1}$ ’onuda çevre bilincinin gelişmeye başladığının göstergelerinden irisj̧iriril 15. Toprak ve yaprak analizi yaptırmak için istonilonlor

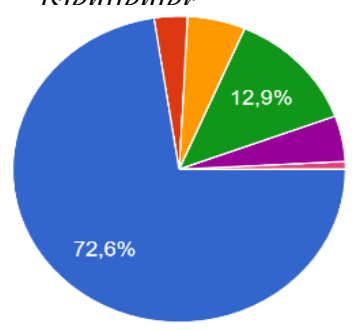

Kompost yapiyorum Yakıyorum Çöp kutusuna atıyorum Seranın içerisine koyuyo। Seranın dışarısına koyuy Bitkisel atık olmuyor Diğer

Şekil 16. Bitkisel atıkların değerlendirilme durumu

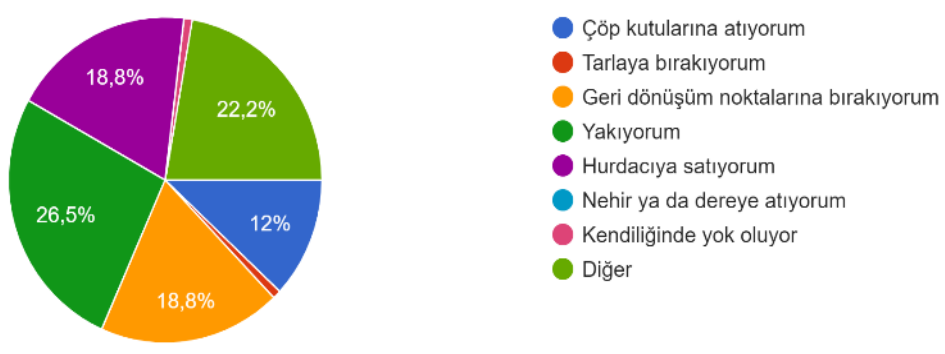

Şekil 17. Örtü malzemesinin geri dönüşümü (PE)

\section{Sonuçlar ve Öneriler}

Yapılan değerlendirmelerde ortaya çıkan sonuçlara göre, Manavgat ilçesi ve yöresindeki seralarda pestisit ve gübre uygulamalarında hataların yapıldığı ancak uygulamalarda düzelmelerin olduğu gözlenmiştir. Özellikle tarımsal kuruluşların ve çevre etkilerinin sıklıkla bahsedilmesinin bu iyileşmeyi artırdığı düşünülmektedir. Üreticilerin hasat sonucu dış ortama bıraktığ 1 bitkisel atıklar, plastik malzemeler, gübreleme sonucu oluşan atıkların genellikle uygun bir şekilde bertaraf edilmeye çalışıldığı ancak yeterli düzeyde olmadığı belirlenmiştir. Üreticilerin ekonomik koşulları, üretilen ürünlerin pazarlama şartları, kullanılan gübre, ilaç, fide, işçilik, örtü malzemesi gibi üretim sezonu boyunca kullandığı tüm parametrelerin ücretlerindeki değişime bağlı olarak atıkları daha bilinçli kullandığı ortaya çıkmıştır. Bu ivmelenmenin devam etmesi arzulanmakta olup, çevre bilincinin gelişebilmesi için gerek kamu çalışanlarının gerekse özelde çalışan Ziraat Mühendislerin tarımsal yayım çalışmalarına katkıda bulunması beklenmektedir. Yapılan araştırmaya göre üreticilerde daha iyi bir çevre bilincinin oluşabilmesinin ancak verimli ve süreklilik isteyen bir yayım süreci ile sağlanabileceği sonucuna varılmıştır. Belirli zamanlarda üreticiler ile bir araya gelerek gerekli eğitimlerin verilmesi ve sertifikasyon süreçleri bu anlamda büyük rol oynamaktadır. Yetiştiricilikte kullanılan gübre ve pestisitlerin yeniden dönüştürülebilir şekilde devlet desteği ile alınması çevre kirliliği açısından bir önlem oluşturabileceği ön görülmektedir. Bilindiği üzere, Çevre ve Şehircilik Bakanlığı tarafından çevre kirliliğinin azaltılmasına yönelik olarak uygulamaya konulan market ürünlerinde kullanılan plastik poşetlerin ücretli olması kullanım miktarlarını azaltmıştır. 


\section{Kaynaklar}

Anonim, 2014. Atıklar ve Çevreye Etkileri.. https://www.bilgiustam.com/atiklar-ve-cevreye-etkileri/

(Erisim Tarihi: 01.03.2020)

Anonim, 2015. FAO Reports the State of Food in Security in the World http://www.fao.org/3/a-i4646e.pdf Erişim tarihi ve adresi: 03.05.2018 (English)

Baytorun (2016), Seralar, Sera Tipleri, Donanım ve İklimlendirilmesi. Nobel Akademik Yayıncılık Eğitim ve Danışmanlık Tic.. Ltd.şti.Yayın No: 1654

Büyüktaş, K., Atılgan, A., Tezcan, A. 2016. Tarımsal Üretim Yapıları. SDÜ Ziraat Fakültesi Yayınları: 101, Ders Kitab1, Isparta, 253s.

Anonim, 2021a. Türkiye İstatistik Kurumu (TÜİK), 2020 Yılına Ait Türkiye Örtüaltı Alanı Miktarı Verileri https://biruni.tuik.gov.tr/medas/?kn=92\&locale=tr (Erişim Tarihi: 16.06.2021)

Anonim, 2021b. Vikipedi, Manavgat (İklim ve Bitki Örtüsü, Coğrafi Konum, Ekonomi). https://tr.wikipedia.org/wiki/Manavgat (Erişim Tarihi: 03.08.2021)

Atılgan, A., Coşkan, A., Saltuk, B., Erkan, M. 2007. Antalya Yöresindeki Seralarda Kimyasal ve Organik Gübre Kullanım Düzeyleri ve Olası Çevre Etkileri, Ekoloji, 15(62):37-47.

Boyacı, S., Akyüz, A., Baytorun, A.N., Çaylı, A. 2016. Kırşehir İlinin Örtüaltı Tarım Potansiyelinin Belirlenmesi Nevşehir Bilim ve Teknoloji Dergisi 5(2):142-157 2016 DOI: 10.17100/nevbiltek.284738.

Boyac1, S. 2018. Kırşehir ve Antalya İlleri İçin Seraların Is1 Gereksiniminin Belirlenmesi ve Isıtmada Kullanılan Enerji Kaynaklarının Karşılaştırılması. Kahramanmaraş Sütçü İmam Üniversitesi Tarım ve Doğa Dergisi 21(6): 976-986. doi: 10.18016/ksutarimdoga.vi.464627

Oğuz, C., Karakayacı, Z., 2017. Tarım Ekonomisinde Araştırma ve Örnekleme Metodolojisi, Atlas Akademi 1. Basım ISBN:978-605-82785-2-3 Konya.

Denizli, A., Yavuz, H., 2017. Mikroplastikler ve Dünyamız. TÜBA-Günce Dergisi, (55), 64-66.

Durak, S.G., 2016. Investigation and Evaluation of the Effect to Environmental Pollution of Plastic Shopping Bags. Turkish Journal of Scientific Reviews, 9(2), 20-24.

Eker M.M. 2012. Jeotermal Seralarda Hedef, 30 Bin Hektar. Jeotermal Belediyeler Dergisi Sayı 6. s.5-14 6: http://jkbb.org.tr/User_Files/jkbb_dergi_6.pdf (Erişim Tarihi: 01.02.2020).
Ertop H., Atılgan A. 2017. The Determination of Properties of Heatiig and Cooling Systems In Greenhouse. Infrastruktura i Ekologia Terenów Wiejskich. Nr 2017/ III (2), Page: 11151129.

Ertop. H., 2017. Seralarda Isıtma ve Serinletme Özelliklerinin Belirlenmesi. Süleyman Demirel Üniversitesi Fen Bilimleri Enstitüsü, Yüksek Lisans Tezi, 101s, Isparta.

Emekli, N.Y., Büyüktaş, K. 2009. Mersin İli Anamur İlçesindeki Muz Seralarının Mevcut Durumu Üzerine Bir Araştırma. Akdeniz Üniversitesi, Ziraat Fakültesi Dergisi. Vol.: 22 (1):23-38.

Güzey, S., Atılgan, A. 2015. Sera Yetiştiriciliğinde Kirletici Faktörlerin Belirlenmesi: Denizli İli Örneği, Süleyman Demirel Üniversitesi Ziraat Fakültesi Dergisi 10 (2):22-33.

Jack T. Trevors, 2001. Water, Air and Soil Pollution. An International Journal of Environmental Pollution. Volume 128 , Issue $3 / 4$.

Kalıpçı, N., Özdemir, C. ve Öztaş, H. 2011. Çiftçilerin Pestisit Kullanımı ile İlgili Eğitim ve Bilgi Düzeyi ile Çevresel Duyarlılıklarının Araştırılması. Tübav Bilim Dergisi 4 (3): 179-187.

Kilıçer, E., 2018. Plastik Poşet Vergisi ve Örnek Ülke Uygulamalar1. Vergi Sorunlar1 Dergisi, (357), 55-64

Kızıloğlu Algan, F., T., Bilen, S., 2005. Toprak Kirlenmesi ve Biyolojik Çevre. Atatürk Üniversitesi Ziraat Fakültesi Dergisi, 36 (1), 83-88.

Parlakay, O., Çelik, A., Kızıltuğ, T. 2015. Hatay İlinde Tarımsal Üretimden Kaynaklanan Çevre Sorunları ve Çözüm Önerileri, Mustafa Kemal Üniversitesi Ziraat Fakültesi Dergisi, Hatay, 1300-936620(2):17-26.

Tanrıvermiş, H., 2000. Orta Sakarya Havzası'nda Domates Üretiminde Tarımsal İlaç Kullanımının Ekonomik Analizi. Ankara Üniversitesi. Proje Raporu 2000-4

Tiryaki, O., Canhilal, R., Horuz, S., 2010. Tarım İlaçları Kullanımı ve Riskleri. Erciyes Üniversitesi Fen Bilimleri Enstitüsü Dergisi, 26(2), 154-169.

Tüzel, Y., G.B. Öztekin, 2015. Protected Cultivation in Turkey. Chronica Horticulturare, 55(2):21-26.

Yüzbaşıŏlu, R., 2019. Tokat İli Merkez İlçe Kırsalında Üreticilerin Toprak Analizi Yaptırma Eğilimleri. Bahri Dağdaş Bitkisel Araştırma Dergisi, 8 (1), 163-169. 